\title{
PENGARUH PENDEKATAN CONTEXTUAL TEACHING AND LEARNING DISERTAI MEDIA AUDIO VISUAL TERHADAP HASIL BELAJAR SISWA
}

\author{
Ani Nuratika ${ }^{1}$, Lisa Utami ${ }^{2}$, Zona Octarya ${ }^{3}$ \\ UIN Suska Riau \\ *Email: lisa.utami@uin-suska
}

\begin{abstract}
Abstrak
Penelitian ini merupakan penelitian eksperimen semu, yang dilatarbelakangi oleh rendahnya prestasi belajar siswa pada mata pelajaran kimia. Hal ini bertujuan untuk mengetahui pengaruh pendekatan Contextual Teaching and Learning (CTL) dengan media audio visual terhadap hasil belajar siswa pada mata pelajaran Hidrokarbon di SMA Negeri 11 Pekanbaru. Desain penelitian ini adalah eksperimen dengan pretest dan posttest. Teknik simple random sampling digunakan dalam penelitian ini, dengan siswa kelas sebelas MIA 2 (kelompok eksperimen) dan 3 (kelompok kontrol). Pengumpulan data dilakukan melalui wawancara, tes data awal berupa tes homogenitas, tes data akhir berupa pretest dan posttest, observasi, dan dokumentasi. Hasil pengolahan data menunjukkan $t_{\text {hitung }}$ sebesar 3,61 dan $t_{\text {tabel }}$ 1,669. Hal ini menunjukkan bahwa $t_{\text {hitung }}$ lebih tinggi dari $t_{\text {tabel}}$, sehingga $\mathrm{H}_{0}$ ditolak dan $\mathrm{H}_{\mathrm{a}}$ diterima. Artinya ada pengaruh pendekatan Contextual Teaching and Learning (CTL) dengan media audio visual terhadap prestasi belajar kimia, dengan koefisien pengaruhnya sebesar $16 \%$.
\end{abstract}

Kata kunci : Contextual Teaching and Learning (CTL), Audio Visual Media, Learning Achievement, Hidrokarbon

\begin{abstract}
This research was a quasi-experiment, it was instigated by the low of student learning achievement on Chemistry subject. It aimed at knowing the effect of Contextual Teaching and Learning (CTL) approach with audio visual media toward student learning achievement on Hydrocarbon lesson at State Senior High School 11 Pekanbaru. Pretest and posttest were the design of this research. Simple random sampling technique was used in this research, and it was obtained the eleventh-grade students of MIA 2 (experimental group) and 3 (control group). The data were collected through interview, preliminary data test that was homogeneity test, final data tests that were pretest and posttest, observation, and documentation. The results of processing the data showed that tobserved was 3.61 and ttable was 1.669. It revealed that tobserved was higher than $t$ table, so $H_{0}$ was rejected and $H_{a}$ was accepted. It meant that there was an effect of Contextual Teaching and Learning (CTL) approach with audio visual media toward chemistry learning achievement, and the coefficient of effect was $16 \%$.
\end{abstract}

Keywords : Contextual Teaching and Learning (CTL), Audio Visual Media, Learning Achievement, HydrocarboN

\section{Pendahuluan}

Perkembangan ilmu pengetahuan dan teknologi telah menghasilkan inovasi diberbagai bidang termasuk bidang pendidikan. Inovasi pendidikan yang dimaksud adalah ide dan metode yang dirasakan atau diamati sebagai sesuatu yang baru oleh 
seseorang atau sekelompok orang (masyarakat) yang digunakan untuk mencapai tujuan tertentu dalam pendidikan (Novaliana, 2015).

Pendidikan merupakan faktor yang sangat penting bagi kehidupan manusia dalam membentuk manusia yang berkualitas. Banyak faktor yang mempengaruhi mutu pendidikan, diantaranya adalah pendekatan-pendekatan pembelajaran yang digunakan para guru dalam proses pembelajaran. Ketepatan menggunakan pendekatan pembelajaran dapat membantu memperbaiki mutu pendidikan dan meningkatkan hasil belajar siswa. Pendidikan juga tidak lepas dari peranan seorang guru. Guru, peserta didik, dan kurikulum merupakan tiga komponen utama dalam sistem pendidikan nasional. Sehingga dalam proses pembelajaran guru harus memiliki kemampuan untuk membuat pembelajaran yang kreatif, variatif dan inovatif, dengan tujuan agar siswa dapat tertarik dalam mengikuti proses belajar mengajar yang dilaksanakan oleh guru,sehingga tujuan pembelajaran dapat tersampaikan dengan optimal (Agus, 2016).

Kimia merupakan ilmu yang termasuk dalam rumpun IImu Pengetahuan Alam (IPA). Ilmu kimia memiliki beberapa karakteristik yaitu sebagian besar ilmu kimia bersifat abstrak. Secara garis besar pembelajaran kimia memiliki tujuan untuk mempelajari fakta dari suatu sistem kimia dan mencari serta menyusun teori yang dapat menjelaskan fakta-fakta kimia. Oleh karena itu dalam proses pembelajaran, penyajian materi kimia perlu dibuat menarik, menyenangkan sehinga siswa mampu memahami konsep tersebut secara mandiri.

Berdasarkan hasil observasi dan wawancara dengan ibu Heni Guspita S.Pd selaku guru kimia kelas XI IPA di Sekolah Menengah Atas Negeri 11 Pekanbaru, diperoleh informasi bahwa permasalahan yang terdapat pada sekolah tersebut adalah hasil belajar siswa yang masih tergolong rendah dari kriteria ketuntasan minimal (KKM) 71 yang ditetapkan oleh sekolah untuk mata pelajaran kimia. Hal ini dapat dilihat dari hasil nilai ulangan siswa pada materi hidrokarbon yaitu pada kelas XI MIA 1 didapatkan $17,40 \%$ tuntas dan $82,6 \%$ tidak tuntas dari 28 jumlah siswa dikelas. Pada kelas XI MIA 2 didapatkan $11,77 \%$ tuntas dan $88,23 \%$ tidak tuntas dari 27 jumlah siswa dikelas. Pada kelas XI MIA 3 didapatkan 12,12\% tuntas dan 87,88\% tidak tuntas dari 28 jumlah siswa dikelas, sedangkan pada kelas XI MIA 4 didapatkan 20,28\% tuntas dan $79,72 \%$ tidak tuntas dari 29 jumlah siswa dikelas. Rendahnya hasil belajar siswa disebabkan 
karena beberapa faktor seperti, siswa banyak yang tidak tertarik belajar kimia, dan siswa menganggap pelajaran kimia merupakan pelajaran yang sulit.

Kesulitan siswa dalam mempelajari ilmu kimia dapat bersumber pada kesulitan dalam memahami istilah dalam teori, sulit memahami konsep, dan kesulitan dalam angka pada perhitungan. Salah satu materi kimia yang dianggap sulit adalah Hidrokarbon. Hidrokarbon merupakan materi pelajaran kimia yang diajarkan pada jenjang pendidikan SMA, yang menjelaskan tentang senyawa karbon yang erat kaitannya dengan kehidupan sehari-hari seperti karbohidrat, lemak, hasil pembakaran dan lain-lain (lis, 2015). Oleh karena itu didalam proses belajar mengajar siswa cenderung menggunakan sistem menghapal, dengan menggunakan sistem hapalan maka pelajaran akan cepat terlupakan oleh siswa. Untuk itu diperlukan pendekatan pembelajaran yang mampu mengaitkan kedalam kehidupan sehari-hari sehingga siswa akan mudah ingat dengan materi yang dipelajari. Salah satu pendekatan pembelajaran yang mengaitkan materi kedalam kehidupan sehari-hari adalah pendekatan Contextual Teaching and Learning (CTL).

Pendekatan CTL merupakan pendekatan belajar yang membantu guru mengaitkan antara materi yang diajarkannya dengan situasi dunia nyata siswa dan mendorong siswa membuat hubungan antara pengetahuan yang dimilikinya dengan penerapannya dalam kehidupan mereka sebagai anggota keluarga dan masyarakat (Suprianto, 2016). Nurhadi menyatakan bahwa, "Pembelajaran kontekstual (Contextual Teaching and Learning) adalah konsep belajar yang membantu guru mengaitkan antara materi yang diajarkannya dengan situasi dunia nyata siswa dan mendorong siswa membuat hubungan antara pengetahuan yang dimilikinya dengan penerapannya dalam kehidupan sehari-hari, dengan melibatkan tujuh komponen utama pembelajaran efektif yakni kontruktivisme, bertanya, menemukan, masyarakat belajar, pemodelan, refleksi dan penilaian sebenarnya" (Kharismayani, 2017).

Selain menggunakan pendekatan CTL, adapun penggunaan media dalam pembelajaran juga sangat penting. Penggunaan media pembelajaran dapat membantu guru dalam menyampaikan materi pembelajaran dan membuat metode pengajaran menjadi lebih bervariasi. Fungsi media dalam proses belajar mengajar yaitu untuk meningkatkan daya tarik peserta didik dalam kegiatan belajar. 
Penggunaan media pembelajaran yang dimaksud yaitu media audio visual. Media audio visual bukan hanya dipandang sebagai alat bantu guru, melainkan juga berfungsi sebagai penyalur pesan belajar. Selain itu, menggunakan media audio visual dapat membuat pelajaran abstrak menjadi lebih konkret (Santi, 2016). Media audio visual yang digunakan dalam penelitian ini berupa rekaman video, slide suara, gambar dan lain-lain. Dengan menggunakan media audio visual dapat memperlancar pemahaman dan memperkuat ingatan siswa. Selain itu media audio visual juga dapat menumbuhkan minat belajar siswa dengan adanya minat akan mempengaruhi hasil belajar siswa. Hasil belajar merupakan suatu akibat dari proses belajar mengajar yang didapat peserta didik berupa kemampuan kognitif, afektif, dan psikomotorik yang dapat dilihat setelah proses pembelajaran dilaksanakan.

Dari penelitian yang dilakukan oleh Suprianto, disimpulkan bahwa pendekatan Contextual Teaching and Learning dapat mempengaruhi hasil belajar siswa. Hasil penelitian menunjukkan bahwa melalui pendekatan CTL hasil belajar siswa lebih baik secara signifikan dari pada pembelajaran konvensional. Hal tersebut terjadi karena metode CTL menggunakan konsep yang kontekstual, dimana langsung menghubungkan aktivitas dengan dunia nyata sehingga mampu menarik dan merangsang siswa untuk belajar statistic (Suprianto, 2016).

Dan penelitian yang dilakukan oleh Joni Purwono, Sri Yutmini, Sri Anitah, hasil data analisis menunjukkan bahwa hasil belajar siswa setelah penggunaan media audio visual mengalami peningkatan dibandingkan dengan sebelum menggunakan media audio visual. Hal ini diperoleh dari hasil ujian tengah semester bahwa terdapat 25 kelas (90\%) dengan pencapaian KKM diatas $80 \%$ (Joni, 2014). Oleh karena itu, penulis tertarik untuk mengadakan penelitian dengan judul "Pengaruh Pendekatan Contextual Teaching And Learning (CTL) Disertai Media Audio-Visual Terhadap Hasil Belajar Siswa Pada Materi Hidrokarbon Di SMA Negeri 11 Pekanbaru"

\section{Metode}

Penelitian ini adalah penelitian quasi eksperimen yang dilakukan terhadap dua kelas, yaitu kelas eksperimen dan kelas kontrol. Pada kelas eksperimen diberikan perlakuan penerapan pendekatan Contextual Teaching and Learning (CTL) disertai 
media audio visual, sedangkan kelas kontrol diberi perlakuan pembelajaran biasa seperti metode diskusi dan tanya jawab melalui media audio visual. Sebelum diberikan perlakuan, kedua kelas terlebih dahulu diberikan pretest, setelah diberikan perlakuan selanjutnya diberikan postest. Selisih nilai pretest dan posttest antara kelas eksperimen dan kelas kontrol merupakan data yang digunakan untuk melihat pengaruhnya terhadap hasil belajar siswa setelah diberikan perlakuan.

Tabel I.Rancangan penelitian pretest dan posttest

\begin{tabular}{cccc}
\hline Kelompok & $\begin{array}{c}\text { Pre- } \\
\text { test }\end{array}$ & Perlakuan & $\begin{array}{c}\text { Post- } \\
\text { test }\end{array}$ \\
\hline Eksperimen & $\mathrm{T}_{1}$ & $\mathrm{X}_{1}$ & $\mathrm{~T}_{2}$ \\
\hline Kontrol & $\mathrm{T}_{1}$ & $\mathrm{X}_{2}$ & $\mathrm{~T}_{2}$ \\
\hline
\end{tabular}

$\mathrm{T}_{1}=$ Data awal (data sebelum perlakuan)

$\mathrm{X}_{1}=$ Perlakuan pendekatan Contextual Teaching and Learning (CTL) disertai media audio visual

$\mathrm{X}_{2}=$ Perlakuan pendekatan saintific disertai media audio visual

$\mathrm{T}_{2}=$ Data akhir (data setelah perlakuan)

Penelitian ini dilaksanakan pada tanggal 20 Juli sampai 10 Agustus 2018 sebanyak 4 kali pertemuan pada semester ganjil tahun ajaran 2018/2019 dikelas XI SMA Negeri 11 Pekanbaru. Populasi dalam penelitian ini adalah seluruh peserta didik kelas XI SMAN 11 Pekanbaru semester ganjil yang terdiri dari 3 kelas pada tahun pelajaran 2018/2019 yang berjumlah 102 peserta didik. Sampel dalam penelitian ini ada dua kelas yang memiliki rata-rata nilai yang hampir sama, yakni kelas XI MIA 2 sebagai kelas eksperimen yang berjumlah 33 peserta didik dan kelas XI MIA 3 sebagai kelas kontrol, yang berjumlah 34 peserta didik.

Teknik pengambilan sampel yang digunakan adalah probability sampling yaitu simple random sampling. Teknik ini dilakukan setelah semua kelas di uji homogenitas dengan uji varians. Uji homogen yang dilakukan peneliti di ambil dari nilai soal Redoks. Teknik pengumpulan data dalam penelitian ini menggunakan tes (homogenitas, pretest dan postest), wawancara, observasi dan dokumentasi. Instrumen yang akan digunakan dalam penelitian, sebelumnya harus diketahui apakah sudah baik atau belum dengan cara melakukan uji validitas lembar instrument. Untuk memperoleh soal-soal tes yang 
baik sebagai alat pengumpul data pada penelitian ini, maka diadakan uji coba yang tidak terlibat dalam sampel penelitian ini. Soal-soal yang diuji cobakan kepada peserta didik dianalisis untuk mengetahui validitas, reliabilitas, daya pembeda dan tingkat kesukaran soal.

Teknik analisis data terdiri dari uji prasyarat dan uji hipotesis. Uji normalitas digunakan untuk mengetahui apakah sampel penelitian ini dari populasi yang normal atau tidak. Sedangkan uji homogenitas digunakan untuk mengetahui apakah sampel penelitian ini dari populasi yang homogen atau tidak. Dalam penelitian ini, uji normalitas yang digunakan adalah metode Kolmogorov-Smirnov dengan bantuan SPSS. Sedangkan untuk menguji Homogenitas digunakan metode Barlett. Uji Hipotesis

\section{Hasil dan Pembahasan}

Data dianalisis dengan menggunakan uji Bartlett pada taraf fignifikan 5\% didapatkan X2hitung < x2tabel atau 0,04 < 5,991 yang dapat disimpulkan bahwa sampel homogen. Sehingga dalam pengambilan sampel dapat menggunakan teknik simple random sampling dan dipilih kelas XI MIA 2 sebagai kelas eksperimen dan XI MIA 3 sebagai kelas kontrol. Teknik simple random sampling merupakan teknik pengambilan sampel sederhana karena pengambilan anggota sampel dari populasi dilakukan secara acak tanpa memperhatikan strata yang ada dalam populasi, cara demikian dilakukan bila anggota populasi dianggap homogen.

Instrumen dalam penelitin ini yaitu soal pilihan ganda sebanyak 30 soal yang telah diuji validitas, reliabilitas, daya beda, dan tingkat kesukaran soalnya. Soal ini digunakan sebagai soal pretest dan Posttest. Uji instrumen ini dilakukan terhadap siswa yang pernah mempelajari materi hidrokarbon. Hasil uji coba soal kemudian dianalisis untuk mengetahui validitas, reliabilitas, tingkat kesukaran soal, dan daya pembeda soal.

Dalam penelitian ini, peneliti menggunakan dua jenis validitas yaitu validitas isi dan validitas empiris. Validitas isi pada pokok bahasan hidrokarbon sebanyak 30 butir soal pilihan ganda. Validitas isi dilakukan oleh pembimbing dan juga guru bidang studi kimia SMA Negeri 11 Pekanbaru yang mengajar di kelas eksperimen dan kelas kontrol. Data hasil validitas yang dilakukan guru bidang studi kimia dapat dilihat pada tabel berikut: 
Tabel II. Validitas Isi Butir Soal

\begin{tabular}{llll}
\hline No & Kriteria & Nomor Soal & Persentase \\
\hline 1 & Valid & $1-30$ & $100 \%$ \\
2 & Tidak Valid & - & $0 \%$ \\
\hline Jumlah & & $\mathbf{3 0}$ & $\mathbf{1 0 0 \%}$ \\
\hline
\end{tabular}

Dari rangkuman di atas dapat dinyatakan bahwa soal tersebut sesuai dengan indikator dan layak digunakan sebagai instrumen penelitian.

Validitas empiris ini dilakukan dengan cara membandingkan product moment (rxy) dan $r_{\text {tabel }}$ dengan taraf signifikan $\alpha=0,05$, diperoleh 21 soal yang valid. Perhitungan validitas empiris soal digunakan bantuan Software Anates versi 4.0.5. Uji reliabilitas digunakan untuk mengetahui sejauh mana alat ukur yang digunakan dapat memberikan gambaran yang benar-benar dapat dipercaya. Berdasarkan analisis uji coba soal yang telah dilakukan dengan menggunakan bantuan software Anates versi 4.0.5, diperoleh nilai reliabilitas soal sebesar 0,83 yang termasuk dalam kategori sangat tinggi.

Sebelum dilakukan proses pembelajaran, terlebih dahulu peneliti melakukan uji pretest terhadap kedua sampel yaitu kelas eksperimen dan kelas kontrol. Tujuan dilakukannya pretest adalah untuk mengetahui sejauh mana kemampuan peserta didik dalam menjawab soal dan sejauh mana peserta didik mengetahui materi hidrokarbon yang mana materi tersebut belum mereka pelajari sebelumnya. Pretest ini dilakukan juga untuk mengetahui perubahan hasil belajar peserta didik yang mana nanti hasil pretest akan dibandingkan dengan hasil posttest di akhir penelitian.

Setelah dilakukan pretest di dua kelas tersebut maka didapatlah hasil nilai ratarata pretest kelas eksperimen sebesar 29,24 dan kelas kontrol sebesar 27,79. Nilai pretest ini merupakan nilai rata-rata ketika peserta didik belum memasuki materi hidrokarbon. Peserta didik masih belum banyak mengetahui materi hidrokarbon tersebut. Peserta didik masih bingung karena belum mempelajari materi yang diberikan, mereka mengisi jawaban hanya sebatas pengetahuan yang mereka ketahui serta pengalaman mereka dalam kehidupan sehari-hari. Hasil yang rendah ini menunjukkan bahwa kelas eksperimen dan kelas kontrol sama-sama belum menguasai materi hidrokarbon. 
Setelah diterapkan pendekatan Contextual Teaching and Learning (CTL) disertai media audio visual pada kelas eksperimen dan pendekatan Saintific disertai media audio visual pada kelas kontrol, maka dilakukan posttest. Nilai postest masing-masing kelas mengalami peningkatan dari pretest karena peserta didik sudah mempelajari materi yang terkait yaitu hidrokarbon. Kelas eksperimen memiliki nilai rata-rata postest sebesar 77,87 sedangkan nilai rata-rata posttest kelas kontrol sebesar 65,64 . Kelas eksperimen memiliki nilai rata-rata yang lebih tinggi dari pada kelas kontrol, sedangkan soal postest yang diberikan adalah sama yaitu 20 soal pilihan ganda materi hidrokarbon. Berdasarkan nilai postest yang diperoleh oleh peserta didik, dapat dilihat masih ada peserta didik yang nilainya berada dibawah KKM, namun rata-rata nilai posttest kelas eksperimen dan kelas kontrol lebih baik dari pada nilai pretest.

Perbandingan nilai pretest dan postest kelas ekperimen dan kelas kontrol dapat dilihat pada Gambar I:

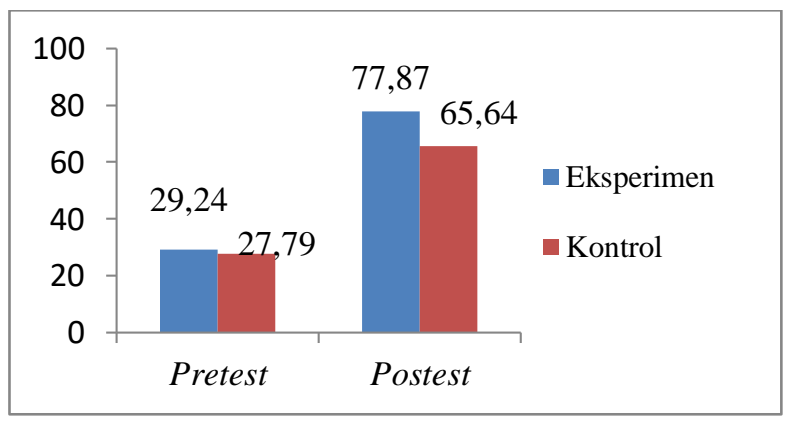

Gambar 1. Grafik Perbandingan Nilai Pretest dan Posttest Kelas Eksperimen dan Kelas Kontrol

Berdasarkan rata-rata perbandingan nilai pretest dan posttest kelas ekperimen dan kelas kontrol diatas pada materi hidrokarbon dapat disimpulkan, bahwa kelas eksperimen menggunakan pendekatan Contextual Teaching and Learning (CTL) memperoleh hasil belajar lebih baik dari pada peserta didik yang belajar dengan menggunakan pendekatan Saintific. Hal ini dikarenakan pemberian perlakuan yang berbeda pada kegiatan pembelajaran didalam kelas. Pada kelas eksperimen guru membimbing siswa untuk mencari informasi dan menemukan konsep sendiri dari materi yang diajarkan sehingga menimbulkan rasa ingin tahu siswa. Sedangkan pada kelas kontrol siswa hanya mencari jawaban sendiri dari pertanyaan tanpa dibimbing. Hal ini senada dengan hasil penelitian Roharjo (2011), menyimpulkan bahwa pendekatan 
pembelajaran Contextual Teaching and Learning (CTL) memiliki pengaruh yang cukup signifikan terhadap hasil belajar siswa, dengan demikian pendekatan Contextual Teaching and Learning memberikan pengaruh yang cukup baik terhadap hasil belajar siswa. Selain itu, didalam pembelajaran menggunakan model pendekatan pembelajaran ini, memberikan motivasi tersendiri dalam kegiatan pembelajaran dan peningkatan kreativitas siswa (Desi, 2014). Hal ini senada dengan hasil penelitian Addani, bahwa CTL dapat meningkatkan hasil belajar siswa (Addani, 2020).

Hal ini sesuai dengan kelebihan pembelajaran Contextual Teaching and Learning (CTL) yaitu pembelajaran lebih produtif dan mampu menumbuhkan penguatan konsep kepada siswa karena metode pembelajaran CTL menganut aliran kontruktivisme, dimana seorang siswa dituntut untuk menemukan pengetahuannya sendiri. Melalui landasan filosofis kontruktivisme siswa diharapkan belajar melalui "mengalami" bukan "menghafal" (Nurhidayah, 2016). Dengan hasil pretest dan postest yang telah didapatkan, maka akan dilakukan analisis data akhir dengan menggunakan rumus test-t, dan diperoleh nilai thitung = sedangkan ttabel = pada taraf signifikan $5 \%$ sehingga thitung $>$ ttabel, yang menyebabkan $\mathrm{H}_{\mathrm{a}}$ diterima dan $\mathrm{H}_{0}$ ditolak (Lampiran $\mathrm{T}$ ). Dan besarnya pengaruh yang didapatkan dapat dilihat setelah analisis menggunakan koefisien pengaruh dengan pengaruh sebesar $16 \%$.

Hal membuktikan bahwa, ada pengaruh pendekatan Contextual Teaching and Learning disertai media audio visual terhadap hasil belajar siswa. Peningkatan yang terjadi pada kelas eksperimen tersebut, disebabkan karena pada kelas eksperimen diberlakukan pendekatan Contextual Teaching and Learning (CTL), disertai media audio visual, sehingga peserta didik bisa lebih mudah memahami materi pelajaran dengan adanya keterkaitan materi yang dipelajarinya dengan kehidupan nyata.

Pada kelas eksperimen yang menggunakan pendekatan Contextual Teaching and Learning (CTL) disertai media audio visual, siswa lebih semangat dan aktif karena dihadapkan dengan demontrasi yang dibantu dengan tayangan video dan gambar yang dilakukan oleh peneliti. Pendekatan CTL dengan media audio visual membuat siswa lebih berfikir kritis dan kreatif dalam mengumpulkan data dan memecahkan masalah. Hal ini terbukti pada saat siswa diberi tugas untuk mengamati demontrasi yang dilakukan oleh guru, siswa berusaha mencari informasi baru, mengumpulkan data-data 
dari hasil penemuan mereka, menganalisis, dan memecahkan masalah dengan cara berdiskusi, saling bertukar pendapat atau saling memberikan gagasan, mencari ide-ide baru, menyimpulkan dan mempresentasikan didepan kelas dengan kompak. Hal ini menunjukkan bahwa secara deskriptif pendekatan CTL menggunakan media audio visual relatif lebih baik sebagai strategi belajar siswa dalam rangka meningkatkan hasil belajar. Peningkatan hasil belajar dengan menggunakan pendekatan CTL disertai media audio visual sejalan dengan pendapat Nurhadi yang menyatakan bahwa, pembelajaran kontekstual (Contextual Teaching and Learning) adalah konsep belajar yang membantu guru mengaitkan antara materi yang diajarkan dengan situasi dunia nyata siswa dan mendorong siswa membuat hubungan antara pengetahuan yang dimilikinya dengan penerapannya dalam kehidupan sehari-hari, dengan melibatkan tujuh komponen utama pembelajaran efektif yakni kontruktivisme, bertanya, menemukan, masyarakat belajar, media dan penilaian sebenarnya.

Dengan adanya pembelajaran CTL ini, siswa lebih antusias dan aktif saat pembelajaran berlangsung. Sesuai dengan penelitan yang dilakukan oleh Gusti Ayu Eka Kharismayani, Lulup Endah Tripalupi, I Nyoman Sujana, setelah dilakukan pembelajaran dengan implementasi pembelajaran kontekstual berbantuan media audio visual menunjukkan terjadi peningkatan hasil belajar siswa. Hal ini ditunjukkan dengan peningkatan skor rata-rata hasil belajar siswa dengan rata-rata kenaikan sebesar 7,45 (Khutni, 2017).

Di dalam penelitiannya Kharismayani, dkk mengatakan bahwa peningkatan hasil belajar dengan implementasi pembelajaran kontekstual berbantuan media audio visual sejalan dengan Nurhadi, dkk yang mengatakan bahwa, pembelajaran kontekstual (Contextual Teaching and Learning) adalah konsep belajar yang membantu guru mengaitkan antara materi yang diajarkan dengan situasi dunia nyata siswa dan mendorong siswa membuat hubungan antara pengetahuan yang dimilikinya dengan penerapannya dalam kehidupan sehari-hari, dengan melibatkan tujuh komponen utama pembelajaran efektif yakni kontruktivisme, bertanya, menemukan, masyarakat belajar, pemodelan, refleksi dan penilaian sebenarnya (Kharismayani, 2017).

Jadi, berdasarkan hasil analisis yang diperoleh dapat disimpulkan bahwa pembelajaran yang diterapkan dengan pendekatan Contextual Teaching and Learning 
(CTL) disertai media audio visual terhadap hasil belajar siswa pada pokok bahasan hidrokarbon SMA Negeri 11 Pekanbaru dengan memperoleh hasil yang lebih baik dari pada pembelajaran yang diterapkan dengan metode saintific disertai media audio visual.

\section{Kesimpulan}

Berdasarkan analisis data, dapat disimpulkan bahwa penggunaan pendekatan Contextual Teaching and Learning (CTL) disertai media audio visual meningkatkan hasil belajar siswa yang lebih tinggi dibandingkan penggunaan metode saintific disertai media audio visual pada materi hidrokarbon di Sekolah Menengah Atas Negeri 11 Pekanbaru.

\section{Daftar Referensi}

Addani, 2020, Pengaruh Model Pembelajaran Contextual Teaching Learning (CTL) Terhadap Hasil Belajar Siswa Pada Materi Suhu dan Kalor, Jurnal Riset Inovasi Pembelajaran Fisika.

Jahro, lis Siti, Ridho, Dimas, 2015, Penerapan Model Problem Based Learning Menggunakan Media Exe Learning untuk Meningkatkan Hasil Belajar dan Kerjasama Siswa Pada Materi Hidrokarbon, Jurnal Pendidikan Kimia, 7(3), hal 8086

Purwono, Joni, Sri Yutmini, Anitah, Sri, 2014, Penggunaan Media Audio-visual Pada Mata Pelajaran IImu Pengetahuan Alam Disekolah Menengah Pertama Negeri 1 Pacitan. Jurnal Teknologi Pendidikan dan Pembelajaran UNS, Hal 127-144.

Kharismayani, Gusti Ayu Eka dkk, 2017, Implementasi Pembelajaran Kontekstual Berbantuan Media Audio Visual untuk Meningkatkan Hasil Belajar Siswa Mata Pelajaran IPS (Ekonomi) Kelas IX H SMP Negeri 2 Blahbatuh Tahun Ajaran 2017/2018, Jurnal Pendidikan Ekonomi Undhiksa, Vol 9, No 2, Hal 247-256.

Khutni, Suwarli Is, dkk, 2017, Penerapan CTL Dalam Meningkatkan Hasil Belajar Siswa Kelas X di SMAN 3 Timang Gajah Pada Materi Hidrokarbon, Prosiding Seminar Nasional MIPA III, ISBN 978-602-50939-0-6, Langsa Aceh 30 Oktober 2017, Hal 135-140.

Nuraini, Desi, 2014, Pengaruh Penggunaan Pembelajaran Contextual Teaching and Learning Terhadap Keterampilan Berfikir Kreatif Siswa Pada Pembelajaran Biologi Kelas X SMA N 1 Bangunrejo tahun pelajaran 2013/2014, Jurnal Bioedukasi, Vol 5 No. 2, Hal 79-86. 
Novalina, Kristha, dkk, 2015, Pengaruh Pendekatan Kontekstual Berbantuan Media Konkrit Terhadap Hasil Belajar IPA Siswa Kelas V SD No. 3 Kerobokan. E-journal PGSD Universitas Pendidikan Ganesha, Vol 3, No. 1.

Nurhidayah, dkk. 2016, Penerapan Model Contextual Teaching and Learning (CTL) Terhadap Hasil Belajar Fisika pada Siswa Kelas XI SMA Handayani Sungguminasa Kabupaten Gowa, Jurnal Pendidikan Fisika 4(1), Hal 162-174.

Purwanto. 2009. Evaluasi Hasil Belajar. Yogyakarta : Pustaka Belajar.

Santi, Nanda Aprilia Vena, dkk, 2016, Penerapan Model Discovery Learning Menggunakan Media Audio Visual Untuk Meningkatkan Hasil Belajar IPA. Ejournal PGSD Universitas Pendidikan Ganesha Jurusan PGSD 4(1), Hal 1-11.

Suprianto, dkk. 2016. Pengaruh Pendekatan Contextual Teaching and Learning (CTL) Berbantuan Media Powerpoint Terhadap Peningkatan Hasil Belajar IPA Fisika. JPPI 2(2), Hal 166-175

Subana. 2010. Statistik Pendidikan. Bandung : Pustaka Setia.

Ridwanulloh, dkk, 2016, Pengaruh Model Pembelajaran Contextual Teaching and Learning (CTL) Terhadap Hasil Belajar Siswa Kelas V Pada Materi Pesawat Sederhana, Jurnal Pena IImiah, Vol. 1 No.1, hal 731-740. 